\title{
ANALISIS IMPLEMENTASI SOCIAL NETWORK SERVICE DI JURUSAN PENDIDIKAN BAHASA INGGRIS UNTUK MENDUKUNG IMPLEMENTASI PENDIDIKAN TEKNOHUMANISTIK
}

\author{
Kusuma, I.P.I \\ Jurusan Pendidikan Bahasa Inggris, \\ Universitas Pendidikan Ganesha, Indonesia \\ E-mail: indrakusuma.eed@gmail.com
}

\begin{abstract}
Abstrak
Social Network Sites (SNS) adalah produk terbaru ICT yang dapat digunakan untuk mendukung pembelajaran di jaman sekarang ini. Penelitian ini bertujuan untuk mendeskripsikan pemanfaatan SNS yang digunakan oleh dosen dan mahasiswa di Jurusan Pendidikan Bahasa Inggris Universitas Pendidikan Ganesha. Penelitian ini termasuk penelitian deskriptif dengan menggunakan pendekatan penelitian campuran. Data pada penelitian ini dikumpulkan dengan menggunakan metode observasi dengan lembar observasi dan pemberian kuesioner dengan memberikan kuesioner kepada mahasiswa. Responden pada penelitian ini adalah 20 dosen dan 100 mahasiswa Jurusan Pendidikan Bahasa Inggris (JPBI). Hasil menunjukan bahwa jumlah dosen yang menggunakan SNS masih sangat sedikit dan jenis yang digunakan tidak beragam. Hasil lainnya adalah mahasiswa menggunakan SNS tidak hanya untuk tuntutan oleh dosen tetapi juga untuk keperluan pembelajaran mereka dikarenakan kesadaran mereka akan pentingnya SNS bagi pembelajaran mereka. Berdasarkan data di atas, dapat disimpulkan bahwa jumlah dosen yang menggunakan SNS untuk perkuliahan masih sangat sedikit sedangkan mahasiswa kerap menggunakan SNS untuk menunjang pembelajaran mereka.
\end{abstract}

Kata Kunci: Social Network Sites, Pemanfaatan SNS, SNS di Perguruan Tinggi

\begin{abstract}
Social Network Sites (SNS) is the latest product of ICT which can be used to support instructions in global era. This study aims at describing the use of SNS conducted by lecturers and students of English Education Department Ganesha University of Education. This study belongs to a descriptive study which uses mix-methods approach. The data was collected by implementing observation and administering questionnaires. The respondents in this study were 20 lecturers and 100 students. The data shows that the lecturer seldom used SNS to support the instructions. Even, the kind used was very limited. Besides, the students used SNS was not only as the requirement from the lecturers, but also they were aware the advantages of using SNS to support their learning. It can be concluded that the lecturers had less awareness of using SNS to support their instructions meanwhile the students mostly used SNS to support their learning.
\end{abstract}

Keywords: Social Network Sites, the use of SNS, SNS in Higher Education

\section{PENDAHULUAN}

Berlakukanya ASEAN Economic Community (AEC) di tahun 2015 sebagai implikasi era global merupakan sebuah batu pijakan bagi komunitas di ASEAN, termasuk Indonesia sebagai salah satu Negara anggota. Hal ini mengindikasikan bahwa ASEAN telah menjadi salah satu pusat ekonomi global di benua Asia. Oleh karena itu, untuk menghadapi tantangan ini, Indonesia mulai berbenah untuk meningkatkan sumberdaya manusianya untuk menghadapi kompetisi terbuka di dalam AEC. Menanggapi fakta di atas, maka Indonesia telah mempersiapkan sumberdaya manusianya untuk mampu 
berbahasa Inggris dikarenakan bahasa Inggris adalah bahasa internasional yang digunakan oleh banyak negara yang memiliki bahasa yang berbeda, termasuk Indonesia. Oleh karena itu, penguasaan bahasa Inggris menjadi sangat khusus di dalam pendidikan Indonesia. Berbagai kebijakan terkait pengajaran bahasa Inggris telah dikeluarkan oleh pemerintah untuk menghasilkan sumberdaya manusia yang berkualitas dan mampu membangun komunikasi dengan bangsa lain. Salah satunya adalah bahasa Inggris di ajarkan sebagai mata pelajaran utama yang juga diujikan pada Ujian Nasional (UN).

Selain penguasaan bahasa Inggris, salah satu ciri menghadapi era global ini adalah penggunaan ICT yang begitu luas. ICT merupakan produk Iptek yang kini mempengaruhi manusia dalam menjalani kehidupan sehari-hari yang semakin maju. Seperti yang dikemukakan oleh Natajaya dan dantes (2015), perkembangan kehidupan manusia semakin maju dengan ditemukannya iptek oleh manusia untuk menjawab permasalahan hidup yang dihadapinya. Penggunaan ini telah menghasilkan dua generasi berbeda yaitu pengguna digital asli (Digital Native) dan imigran digital (Digital Immigrant). Digital Natives adalah pengguna asli ICT dan mengetahui dengan pasti bagaimana menggunakan alat-alat digital dikarenakan mereka lahir di saat penggunaan alat-alat digital mulai marak. Sedangkan Digital Immigrant adalah pengguna alat-alat digital yang tidak lahir di era penggunaan digital namun beradaptasi dengan mulai menggunakan alat-alat digital (Prensky, 2001).

Melihat fakta di atas, Kementerian Pendidikan dan Kebudayaan (Kemdikbud) Indonesia secara serius menanggapi fenomena-fenomena ini di dalam pendidikan Indonesia. Sebagai konsekuensinya, Kemdikbud telah mengeluarkan Peraturan Menteri No. 65 Tahun 2013 di mana guruguru, termasuk guru bahasa Inggris, harus mampu menggunakan ICT di dalam pengajaran. Untuk mendukung keputusan ini, Kemdikbud bersama Kementerian Komunikasi dan Informasi (Kominfo) beserta universitas-universitas di Indonesia bersama-sama menjalankan program pelatihan penggunaan alat-alat ICT di dalam pembelajaran. Selain itu, Kemdikbud dan Kominfo bersama-sama memfasilitasi areaarea terluar dengan fasilitas ICT yang telah dilaksanakan sejak tahun 2015 sebagaimana yang disampaikan melalui situs resmi Kemdikbud.

Melihat fakta bahwa bahasa Inggris dan penggunaan ICT sangat penting untuk menghadapi era global dan AEC, maka pengajaran bahasa Inggris dan ICT sangatlah penting. Bahkan pengajaran bahasa Inggris bisa dilakukan dengan penggunaan ICT di dalam pelaksanaannya. Hal ini perlu untuk dilaksanakan agar siswa mendapat pengalaman bahasa Inggris yang ditopang dengan penggunaan ICT sehingga mereka nantinya mampu menguasai bahasa Inggris dan penggunaan ICT sebagai bekal di masa depan nantinya.

Oleh karena guru-guru bahasa Inggris harus mampu menerapkan ICT di dalam pembelajaran, maka universitasuniversitas pendidikan di Indonesia harus memberikan pengalaman calon-calon guru bahasa Inggris dengan penggunaan ICT di dalam pembelajaran. Hal ini dimaksudkan agar lulusan ini nantinya mampu menerapkan pengajaran bahasa Inggris ditopang oleh penggunaan ICT. Ditambah lagi, mahasiswa-mahasiswa di jaman sekarang ini termasuk di dalam generasi pengguna asli digital (Digital natives).

Selain itu, pemanfaatan ICT merupakan bagian untuk mendukung Pendidikan Teknohumanistik. Pendidikan Teknohumanistik adalah sebuah model pendidikan yang berdasarkan nilai-nilai etika dan lokal genius yang erat kaitannya dengan pendidikan karakter dan erat kaitannya dengan penggunaan teknologi di era global ini (Dantes, 2004). Sependapat dengan hal ini, Mundiri (2012) menyatakan bahwa model pendidikan masa depan harus berdasarkan kepada nilai-nilai budaya lokal dan mampu menjawab tantangan masa depan dengan penguasaan teknologi dan salah satu model pendidikan yang dapat mewujudkannya adalah Pendidikan Teknohumanistik. Selain itu, Lasmawan (2015) juga menyatakan hal yang sama bahwa Pendidikan Teknohumanistik merupakan sebuah model pendidikan yang mampu menjawab tantangan era globalisasi 
yaitu membentuk pembelajar yang memiliki perpspektif global namun tetap dilandasi dengan nilai-nilai budaya bangsa.

$$
\text { Melihat implemetasi pendidikan }
$$

untuk mendukung Pendidikan

Teknohumanistik di Indonesia, khususnya di dalam pemanfaatan ICT, Kurikulum pendidikan Indonesia telah menisyaratkan bahwa pengajaran hendaknya dilakukan dengan pemanfaatan alat-alat ICT seperti yang tertuang di dalam peraturan yang telah disebutkan di atas. Pemanfaatan ICT pun telah dilaksanakan oleh guru-guru dengan baik yang ditandai dengan penggunaan OHP, video, radio, televise, dll. Namun, perkembangan dunia yang begitu pesat telah melahirkan produk-produk baru ICT. Sehingga ICT tidak lagi mengenai alat-alat yang telah disebutkan di atas. Guru-guru harus mulai belajar menggunakan produk ICT terkini seperti internet, ponsel pintar, world-wibe-web (www), dan social network sites (SNS) seperti BBM, Whatsapp, Line, Facebook dll. yang kini sangat digemari.

Social network sites (SNS) adalah sebuah platform atau situs berbasis online yang digunakan untuk membangun jaringan komunikasi di antara sesama penggunaanya yang notabene memiliki kesamaan latar belakang, hobi, aktivitas, pekerjaan, dsb. (Srivasta, 2012). Sependapat dengan hal ini, Labus, Simic, Barac, Zrakic, \& Radenkovic (2012) menyatakan bahwa "SNS are currently the world's fastest developing personal networking tool and one of the most popular forms of online communication". Jadi dapat disimpulkan bahwa SNS adalah salah atu media komunikasi yang kini berkembang dengan pesat yang digunakan oleh banyak orang. Saat ini sudah banyak produk SNS yang digunakan seperti BBM, Whatsapp, Line, Facebook, e-lerning, youtube, blog, dll. di Indonesia. Melalui penelitian yang dilakukan oleh Triastuti, primadi, dan Rakhmani (2014), masyarakat Indonesia adalah pengguna aktif SNS di mana $50 \%$ $60 \%$ masyarakat Indonesia di setiap provinsi adalah pengguna internet dan SNS. Serta, kebanyakan dari jumlah ini berumur 18-25 tahun.

Dengan banyaknya penggunaan SNS di Indonesia, maka SNS dapat dijadikan pertimbangan untuk digunakan sebagai alat ICT yang mampu diterapkan di dalam pendidikan Indonesia. Jones dkk. (2001) sebagaimana yang dikutip oleh Bicen dan Usunboylu (2013) menyatakan bahwa SNS dapat digunakan untuk memfasilitasi guru dan murid di dalam aktivitas pengajaran dan pembelajaran baik di dalam maupun di luar kelas. berbagai penelitian telah dilakukan oleh peneliti luar terkait dengan penggunaan internet dan SNS di dalam pembelajaran (lihat Brady, Holcomb, \& Smith, 2010; Stanciu, Mihai, \& Aleca, 2012; and Bicen \& Uzunboylu, 2013). Bahkan, penelitian oleh peneliti luar yang terkait dengan efektivitas dan dampak SNS terhadap perkuliahan mahasiswa tidak sedikit jumlahnya (Lihat Tariq, mehboob, Khan, Ullah, 2012; Abao, Boholano, \& Dayagbil, 2015; \& Fori, 2016). Penelitianpenelitian tersebut menyatakan bahwa SNS membawa efek dan dampak yang positif di dalam pendidikan di mana kualitas pembelajaran semakin meningkat dan pembelajaran kini tidak lagi hanya di dalam kelas, tapi dapat dilaksanakan di luar kelas dan kapan saja.

Oleh karena itu, melalui penjelasan di atas maka pemanfaatan SNS haruslah menjadi pertimbangan bagi para pengajar calon-calon guru di Indonesia. Undiksha sebagai salah satu universitas pendidikan ternama di Indonesia yang mencetak caloncalon guru berkualitas, calon guru bahasa Inggris, harus mampu menerapkan SNS di dalam perkuliahan. Dosen Undiksha haruslah mampu menerapkan pemanfaatan SNS di dalam pengajaran untuk memberikan pengalaman bermakna bagi para calon guru untuk mampu menerapkannya di dunia nyata di saat mereka telah menjadi guru. Ditambah lagi, melalui observasi awal yang telah dilakukan di Jurusan Pendidikan Bahasa Inggris diketahui bahwa mahasiswa dan dosen memiliki ponsel pintar dan komputer jinjing, serta kampus telah didukung fasilitas berupa internet yang dapat dimanfaatkan oleh dosen dan mahasiswa.

Namun, data-data mengenai pemanfaatan SNS di dalam universitas pendidikan masih sangat sedikit jumlahnya. Khususnya pemanfaatan ICT untuk mendukung Pendidikan teknohumanistik di Indonesia. Para peneliti kebanyakan 
meneliti budaya lokal dan pendidikan karakter di dalam pendidikan Indonesia dan tidak mengambil fokus di dalam pemanfaatan teknologi di dalam pendidikan itu sendiri (lihat Dantes, 2004 dan Mundiri, 2012). Padahal implementasi ICT di dalam pembelajaran adalah suatu hal baru yang hendaknya mendapatkan perhatian khusus bagi para peneliti di Indonesia, khususnya implementasi produk-produk ICT terbaru yang mampu menopang dan mendukung pendidikan di Indonesia.

Maka, penelitian terkait pemanfaatan SNS di dalam pendidikan di universitas pendidikan sebagai universitas calon pencetak guru-guru di Indonesia sangat perlu untuk dilakukan. Hal ini sangat penting untuk dilakukan agar mendapatkan gambaran yang komprehensif terkait penggunaan ICT di dalam perkuliahan. Melalui hasil penelitian ini nantinya, diharapkan mampu menjadi awal bagi peneliti lainnya untuk melakukan bidang kajian yang sama, serta hasilnya mampu digunakan sebagai bahan pertimbangan di dalam pengambilan keputusan nantinya.

Oleh karena itu, penelitian terkait pemanfaatan SNS di Universitas Pendidikan telah dilakukan. Adapun tempat yang dijadikan penelitian ini adalah Jurusan Pendidikan Bahasa Inggris Universitas Pendidikan Ganesha sebagai salah satu jurusan pencetak calon guru-guru bahasa Inggris yang berkualitas. Adapun subyek di dalam penelitian ini adalah Dosen dan mahasiswa Jurusan Pendidikan Bahasa Inggris di Universitas Pendidikan Ganesha. Sedangkan, tujuan penelitian ini adalah mendeskripsikan pemanfaatan SNS di dalam perkuliahan dan pendapat mahasiswa terkait pemanfaatan SNS untuk meningkatkan kualitas pembelajaran.

\section{METODE}

Penelitian ini merupakan penelitian deskriptif yang bertujuan untuk mendeskripsikan SNS apa saja yang digunakan oleh dosen di Jurusan Pendidikan Bahasa Inggris; mendeskripsikan pemanfaatan SNS oleh mahasiswa di Jurusan Pendidikan Bahasa Inggris; dan mendeskripsikan pendapat mahasiswa di Jurusan Pendidikan Bahasa Inggris terkait pemanfaatan SNS untuk meningkatkan kualitas pembelajaran. Pendekatan pada penelitian ini adalah pendekatan metode campuran (Mixed Methods) dikarenakan menggunakan metode-metode kualitatif dan kuantitatif di dalam pelaksanaannya.

Subyek di dalam penelitian ini adalah dosen dan mahasiswa di Jurusan Pendidikan Bahasa Inggris Universitas Pendidikan Ganesha. Secara lebih spesifik, 20 dosen dan 100 mahasiswa di Jurusan Pendidikan Bahasa Inggris (JPBI) diikutsertakan di dalam penelitian ini. Sedangkan obyek di dalam penelitian ini adalah pemanfaatan SNS di dalam perkuliahan. Yang dimaksud dengan SNS di dalam penelitian ini adalah media ICT atau platform aplikasi yang berbasis internet seperti BBM, Whatsapp, Line, Youtube, Blog, Facebook, E-learning, dan aplikasi berbasis online lainnya yang digunakan di dalam perkuliahan.

Adapun data di dalam penelitian ini dikumpulkan dengan menggunakan metode Observasi dengan menggunakan lembar observasi dan pemberian Kuesioner dengan memberikan kuesioner yang menggunakan rating scale dengan respon Sangat Setuju (SS), Setuju (S), Netral (N), Tidak Setuju (TS), dan Sangat Tidak Setuju (STS). Observasi dilakukan untuk mengetahui SNS apa saja yang digunakan oleh dosen di Jurusan Pendidikan Bahasa Inggris dan Kuesioner diberikan kepada mahasiswa di Jurusan Pendidikan Bahasa Inggris untuk mengetahui pemanfaatan SNS di dalam perkuliahan serta pendapat mereka akan penggunaan SNS untuk meningkatkan kualitas pembelajaran. Data yang telah terkumpul kemudian di analisis secara kualitatif dan kuantitatif.

\section{HASIL DAN PEMBAHASAN}

Data terkait penggunaan SNS yang digunakan oleh dosen yang dikumpulkan melalui implementasi metode observasi dilakukan pertama kali sebelum mengumpulkan data terkait dengan pemanfaatan SNS oleh mahasiswa dan pendapat mereka akan pemanfaatan SNS. Adapun data yang telah terkumpul menunjukan bahwa keseluruhan dosen yang digunakan sebagai subyek di dalam penelitian ini memiliki ponsel pintar dan 
komputer jinjing yang merupakan produk ICT. Ponsel dan komputer jinjing ini digunakan untuk mendukung pekerjaan mereka sebagai dosen seperti berkomunikasi dengan rekan kerja, mahasiswa, dan pihak lainnya, dan juga untuk menyiapkan materi-materi perkuliahan. Selain itu, keseluruhan dosen memiliki SNS yang bisa diakses melalui ponsel pintar maupun komputer jinjing yang mereka miliki.
Namun, data menunjukan bahwa tidak semua dosen menggunakan SNS untuk memfasilitasi pembelajaran. Hanya sebagian dosen yang menerapkan SNS untuk memfasilitasi pembelajaran di kelas. Terkait dengan pemanfaatan SNS di dalam perkuliahan, data yang terkumpul dapat dilihat pada Tabel 1.

Tabel 1. SNS yang digunakan oleh Dosen di Jurusan Pendidikan Bahasa Inggris

\begin{tabular}{|c|c|c|}
\hline No & $\begin{array}{l}\text { Jenis SNS yang digunakan di dalam } \\
\text { pembelajaran }\end{array}$ & Penggunaan \\
\hline 1 & Whatsapp & Komunikasi dan diskusi \\
\hline 2 & E-Learning (Schoology) & $\begin{array}{l}\text { Komunikasi, diskusi, penyampaian } \\
\text { materi, pengumpulan tugas }\end{array}$ \\
\hline 3 & Facebook & Pengumpulan tugas \\
\hline 4 & Blog & Pengumpulan tugas dan diskusi \\
\hline 5 & Email & Pengumpulan tugas \\
\hline
\end{tabular}

Melalui Tabel 1 dapat diketahui bahwa SNS yang digunakan oleh dosen ada 5 macam yaitu Whatsapp, schoology (elearning), Facebook, Blog, dan email. Hanya whatsapp dan schoology yang digunakan untk memfasilitasi komunikasi dan diskusi. Sedangkan SNS lainnya digunakan untuk pengumpulan tugas. Terkait dengan data yang dikumpulkan dengan menggunakan kuesioner yang diberikan kepada mahasiswa mengenai pemanfaatan SNS di dalam perkuliahan, data menunjukan bahwa mahasiswa $100 \%$ menggunakan SNS dalam menunjang pembelajaran mereka. Adapun alasan mereka bervariasi terkait penggunaan SNS ini. Kebanyakan dari mereka berpendapat bahwa SNS mudah digunakan dan sangat membantu mereka dalam pembelajaran mereka di mana mereka bisa melakukan aktivitas dengan menggunakan SNS seperti berdiskusi dan bahkan bisa mencari materi perkuliahan tambahan yang mendukung pembelajaran mereka. Selain itu, mereka menyebutkan jenis SNS yang mereka biasanya gunakan di dalam pembelajaran mereka seperti Whatsapp, Line, Youtube, Blog, Facebook, dan Schoology (E-learning). Penggunaan SNS yang telah disebutkan tadi selain digunakan atas keinginan sendiri, juga mereka nyatakan atas tuntutan perkuliahan yang dilaksanakan oleh dosen. Selain data terkait dengan pemanfaatan SNS, data mengenai pendapat mereka akan penggunaan SNS untuk mendukung perkuliahan dapat dilihat pada Tabel 2.

Tabel 2. Pendapat Mahasiswa terkait Pemanfaatan SNS di dalam Perkuliahan

\begin{tabular}{clcccc}
\hline \multirow{2}{*}{ No } & \multicolumn{1}{c}{ Pernyataan } & \multicolumn{3}{c}{ Respon (\%) } \\
& \multicolumn{1}{c}{ SS } & S & N & TS & STS \\
\hline 1. & Saya mengenal Social Network Sites & 100 & & & \\
2 & Saya dapat menggunakan social Networks sites & 86 & 14 & & \\
3 & $\begin{array}{l}\text { Social Networks Sites dapat membantu proses belajar } \\
\text { saya. }\end{array}$ & 45 & 32 & 23 & \\
4. & Social Networks Sites dapat meningkatkan keinginan & 28 & 34 & 38 & \\
& saya untuk belajar. & & & & \\
\hline
\end{tabular}




\begin{tabular}{clcccc}
\hline \multirow{2}{*}{ No } & \multicolumn{1}{c}{ Pernyataan } & \multicolumn{3}{c}{ Respon (\%) } \\
& \multicolumn{1}{c}{ SS } & S & N & TS & STS \\
\hline 5. & $\begin{array}{l}\text { Social Networks Sites dapat meningkatkan motivasi } \\
\text { saya dalam belajar. }\end{array}$ & 30 & 32 & 38 & \\
6. $\begin{array}{l}\text { Social Networks Sites dapat meningkatkan rasa ingin } \\
\text { tahu saya. }\end{array}$ & 43 & 57 & \\
7. $\begin{array}{l}\text { Social Networks Sites dapat memfasilitasi proses } \\
\text { diskusi pembelajaran. }\end{array}$ & 86 & 14 & \\
8. $\begin{array}{l}\text { Social Networks Sites dapat membantu saya agar lebih } \\
\text { aktif di dalam pelajaran. }\end{array}$ & 48 & 32 & 20 \\
9. $\begin{array}{l}\text { Social Networks Sites dapat membantu dalam } \\
\text { penerapan materi di dalam pembelajaran. }\end{array}$ & 36 & 48 & 16 \\
10. $\begin{array}{l}\text { Social Networks Sites dapat membantu saya untuk } \\
\text { melaksanakan pembelajaran yang mandiri. }\end{array}$ & 58 & 42 & \\
\hline
\end{tabular}

Melalui Tabel 2, diketahui bahwa seluruh mahasiswa menggunakan SNS dan sebagian besar sangat mengetahui bagaimana cara penggunaannya. Serta, sebagian besar mahasiswa menyatakan bahwa penggunaan SNS dapat membantu proses belajar mereka. Tidak kalah penting, bahwa sebagian besar dari mahasiswa menyatakan bahwa SNS dapat membantu mereka dalam proses diskusi terkait dengan pembelajaran mereka. Sebagian besar mahasiswa juga menyatakan bahwa dapat membantu mereka lebih aktif di dalam pembelajaran. Selain itu, mahasiswa juga menyatakan bahwa SNS dapat membantu melaksanakan pembelajaran yang mandiri.

Pemanfaatan ICT merupakan sebuah ciri penting di dalam menghadapi era global sekarang ini. Sehingga, masyarakat dituntut untuk menyadari akan hal ini dan berusaha untuk beradaptasi dengan perubahan-perubahan yang terjadi agar tidak ketinggalan jaman dan mampu bersaing dengan bagsa lainnya. Hal ini pulalah yang ditekankan di dalam Pendidikan Teknohumanistik. Pendidikan teknohumanistik menurut Dantes (2004) adalah sebuah model pendidikan yang berdasarkan nilai-nilai etika dan lokal genius yang erat kaitannya dengan pendidikan karakter dan dan salah satu cirinya adalah penggunaan teknologi sebagai bagian akan kesadaran akan perubahan di lingkungan sekitar.

Perubahan-perubahan ini dapat difasilitasi melalui pendidikan karena melalui pendidikanlah, segala perubahan ini dapat diketahui, dicermati, dan bahkan dipelajari.
Oleh karena itu, dosen dan guru dituntut untuk mampu memfasilitasi perubahanperubahan positif yang terjadi di jaman sekarang ini melalui pendidikan. Sehingga, manusia Indonesia nantinya akan memiliki bekal yang cukup dan mampu bertahan dengan perubahan-perubahan yang terjadi.

Sehubungan dengan perubahan pemanfaatan ICT seperti SNS di era global sekarang ini, melalui data yang telah dikumpulkan terkait dengan pemanfaatan SNS oleh dosen di Jurusan Pendidikan Bahasa Inggris Universitas Pendidikan Ganesha, dapat dikatakan bahwa kesadaran akan implementasi SNS di dalam perkuliahan masih sangat rendah. Tidak semua dosen memanfaatkan SNS untuk memfasilitasi pembelajaran meskipun menurut data mereka menggunakan SNS di dalam kehidupan sehari-harinya.

Ada beberapa kemungkinan yang mampu menjelaskan fenomena yang terjadi ini. Adapun kemungkinan yang pertama adalah karena kebanyakan dosen merupakan Digital Immigrant yang mana mereka tidak terbiasa dengan pemanfaatan ICT, dalam hal ini adalah SNS. Selain itu, bisa jadi mereka bukan pengguna aktif SNS sehingga enggan untuk menggunakan SNS untuk pembelajaran. Data ini didukung oleh hasil penelitian yang dilakukan oleh Triastuti, Primadi, \& Rakhmani (2014) bahwa pengguna internet dan SNS di Indonesia yang merupakan orang dewasa di atas umur 25 tahun hanya berkisar $10-15$ persen saja. Hal ini membuktikan bahwa dosen yang berumur di atas 25 tahun merupakan Digital Immigrant yang tidak terbiasa dengan 
penggunaan ICT di dalam kehidupan mereka, khususnya SNS. Oleh karena itu, pemanfaatan SNS di dalam pembelajaran pun menjadi urung untuk dilaksanakan.

Adapun kemungkinan yang kedua adalah SNS merupakan aplikasi yang digunakan hanya untuk kegiatan personal saja. Hal ini bisa menjadi sebuah kemungkinan di mana sebagian pengguna internet hanya menggunakan SNS sebagai media untuk komunikasi personal sebagai pengganti Short Message Service (SMS). Sehingga, SNS tidak digunakan untuk memfasilitasi untuk kegiatan pembelajaran.

Namun, sebagai insan pembaharu pendidikan, dosen bertugas sebagai agen pembangun pendidikan yang cepat tanggap akan perubahan jaman yang dapat membawa kemuktahiran bagi perkembangan ilmu dan pendidikan itu sendiri. Oleh karena itu, pemanfaatan SNS sudah seharusnya menjadi sebuah hal yang harus dilaksanakan oleh para pengajar. Selain itu, SNS sendiri telah terbukti membawa efek yang positif bagi pembelajaran di perguruan tinggi. Seperti halnya penelitian yang dilakukan oleh Brady, Holcomb, \& Smith (2010). SNS seperti Ning education dapat digunakan sebagai media pembelajaran, khususnya pembelajaran jarak jauh yang secara efektif diimplementasikan untuk kegiatan berdiskusi di dalam pembelajaran. Penelitian lainnya yang dilaksanakan oleh Srivastava (2012) juga menyatakan bahwa SNS memberikan efek yang sangat positif terhadap pembelajaran. Meskipun penelitian ini dilaksanakan di India, namun dia menyatakan bahwa SNS juga digunakan di seluruh dunia dan memberikan efek dan dampak yang positif terhadap pembelajaran. Penelitian lainnya yang juga membuktikan bahwa SNS efektif untuk pembelajaran di perguruan tinggi adalah penelitian yang dilaksanakan oleh Abao, Boholano, \& Dayagbil (2015).

Mereka melakukan penelitian di beberapa perguruan tinggi di Cebu dan menyatakan bahwa penggunaan SNS yang begitu marak telah digunakan sebagai sebuah kesempatan bagi para dosen untuk memfasilitasi pembelajaran di tingkat perguruan tinggi. Melalui hasil penelitian mereka, diketahui bahwa Facebook, sangat bermanfaat bagi peningkatan kualitas pembelajaran di mana penggunaan SNS ini mampu berdampak sangat positif terhadap pembelajaran. Pembelajaran tidak lagi terbatas oleh ruang dan waktu. Melalui SNS, pembelajaran dapat dilakukan kapan dan di mana saja. Melalui pemaparan di atas, maka sudah seharusnya SNS dimanfaatkan sebagaimana mestinya agar dapat meningkatkan kualitas pembelajaran.

Terkait dengan jenis SNS yang digunakan oleh dosen dalam memfasilitasi pembelajaran, maka dosen harus mengetahui dengan benar akan fungsi masing-masing SNS. Hal ini dimaksudkan agar aktivitas pembelajaran dapat difasilitasi dengan penggunaan SNS yang tepat. Sehingga pemanfaatan SNS tertentu nantinya dapat dimanfaatkan seefektif dan seefisien mungkin. Sebagai contoh, Whatsapp Line, dan BBM merupakan media komunikasi berbasis online yang penggunaannya hampir mirip dengan SMS. Namun, melalui SNS yang telah disebutkan tersebut, grup-grup tertentu dapat dibuat untuk memfasilitasi komunikasi serta diskusi di dalam pembelajaran. Contoh lainnya adalah E-Learning, melalui e-learning bermacam aktivitas pembelajaran dapat difasilitasi seperti diskusi, pengumpulan tugas, menjawab pertanyaan, bahkan untuk pemberian materi dalam bentuk dokumen pun dapat dilakukan melalui E-learning itu sendiri.

Namun, tentunya implementasi SNS oleh dosen tidak dapat maksimal apabila mahasiswa sendiri tidak mengetahui bagaimana penggunaan SNS tersebut dan manfaatnya bagi pembelajaran. Tetapi, dalam penelitian ini mahasiswa Jurusan Pendidikan Bahasa Inggris mengetahui dengan pasti cara penggunaan SNS. Hal dimungkinkan karena mereka sendiri merupakan Digital Natives yang menurut penjelasan Prensky (2001) merupakan pengguna ICT asli di mana ICT telah mereka gunakan sejak mereka masih di usia anakanak. Selain itu, mahasiswa JPBI sendiri selain menggunakan SNS sebagai tuntutan perkuliahan, mereka juga menggunakan SNS tanpa diminta oleh dosen untuk keperluan pembelajaran mereka dikarenakan mereka mengetahui dengan baik apa manfaat SNS bagi pembelajaran 
mereka, khususnya untuk perkuliahan. Oleh karena itu, hal ini perlu untuk dimanfaatkan oleh dosen untuk bisa memfasilitasi pembelajaran dengan implementasi SNS dikarenakan mahasiswa sendiri sangat mengetahui manfaat-manfaat SNS bagi mereka, pembelajaran mereka, dan masa depannya nanti, khususnya untuk menjadi sumberdaya manusia yang memiliki kualitas baik dalam menghadapi era global dan persaingan di AEC nantinya.

Begitu banyak manfaat yang bisa didapatkan dengan menggunakan SNS. Salah satunya adalah mahasiswa dapat termotivasi untuk melaksanakan pembelajarannya sendiri atau melaksanakan pembelajaran yang mandiri. Melalui SNS, mahasiswa dapat menambah pengetahuan melalui diskusi dengan teman dengan menggunakan SNS. Hal ini sebagaimana hasil penelitian yang dilakukan di Jordania oleh Doghmi, Shalabi, odeh, Andraws, Awajan, \& Alrabea (2013) bahwa $60 \%$ mahasiswa di Jordania menggunakan SNS untuk berdiskusi dengan teman sejawat terkait dengan materi perkuliahan yang mereka tidak pahami sebelumnya. Tentunya hal ini merupakan sesuatu yang sangat kita harapkan untuk terjadi di pendidikan Indonesia bahwa mahasiswa dapat meningkatkan pemahaman tidak hanya melalui penjelasan dosen, tetapi melalui diskusi yang meskipun dilakukan melalui SNS.

Manfaat lainnya adalah melalui SNS jarak antara mahasiswa dan dosen tidak lagi hanya sebatas di area kampus. Mahasiswa melalui SNS dapat bertanya kepada dosen akan hal-hal yang belum mereka pahami. Bahkan bagi mereka yang tidak bisa ikut pembelajaran di kelas bisa mengetahui apa materi yang dipelajari melalui penggunaan SNS. Seperti yang dinyatakan oleh Khedo, Ally, Suntoo, \& Mocktoolah (2012) bahwa melalui penggunaan SNS, siswa yang absen sekalipun dapat mengejar ketertinggalan mereka melalui penggunaan internet dan SNS.

Tentunya hal-hal yang telah disebutkan di atas sangat memungkinkan terjadinya perubahan dalam paradigma pembelajaran. Belajar tidak lagi hanya dilakukan di dalam kelas, tetapi bisa di luar kelas, pembelajaran tidak harus menunggu penjelasan oleh dosen, tetapi dapat dicari dengan menggunakan SNS, serta materi tidak lagi melalui buku dikarenakan melalui SNS, mahasiswa bisa mendapatkan sumber-sumber materi untuk menunjang pembelajaran mereka. Sangat mungkin nantinya pendidikan tidak lagi terikat dengan pengajaran sebagaimana yang dinyatakan oleh Labus, Simic, Barac, Zrakic, \& Radenkovic (2012) bahwa pendidikan nantinya tidak lagi berkaitan hanya dengan pengajaran tradisional yang dilaksanakan di dalam kelas di mana tahun-tahun mendatang semuanya bisa dilakukan secara online dengan menggunakan bantuan media ICT seperti SNS.

Selain itu, melalui penggunaan ICT diharapkan pendidikan Indonesia mampu menerapkan pendidikan yang benar-benar berpusat pada pembelajar (Students center) di mana saat ini pendidikan Indonesia menyatakan telah menerapkan pendidikan ini ditengah kenyataan bahwa pengajar masih menerapkan cara-cara pembelajaran yang berpusat pada pengajar (Teachers center). Sebagaimana yang dinyatakan oleh Santyasa, Warphala, \& Tegeh (2015), pengajar Indonesia cenderung menggunakan model-model pembelajaran yang berpusat pada guru. Sehingga, penggunaan ICT ini diharapkan mampu untuk mengurangi praktek-praktek model pembelajaran yang berpusat pada pengajar dan lebih menekankan pada pembelajaran yang berpusat pada pembelajar.

Pendidikan Teknohumanistik sangat penting adanya bagi pendidikan di Indonesia. Dewasa ini masyarakat dihadapkan pada situasi yang menuntut adanya perubahan di berbagai lini diakibatkan oleh perkembangan jaman. Dengan demikian, pendidikan juga harus menyesuaikan dengan perubahanperubahan yang terjadi. Sehingga, pendidikan haruslah memiliki inovasi-inovasi baru dalam menghadapi perubahan jaman tersebut dengan tidak mengindahkan nilainilai norma dan budaya yang berlaku di mana masyarakat itu berada.

Penggunaan ICT dan bahasa Inggris merupakan sebagian perubahan di era sekarang ini yang harus dapat disadari oleh masyarakat Indonesia untuk menghadapi persaingan global. Melalui Pendidikan 
teknohumanistik, pembelajar akan memperoleh bekal untuk menghadapi tantangan di era global nantinya. Melalui Pendidikan Teknohumanistik pula, masyarakat Indonesia nantinya bisa menjadi insan yang mandiri yang memiliki karakter dan nilai-nilai kemanusiaan yang baik serta memiliki kualitas yang mumpuni di masa depan seperti memiliki kualitas di bidang yang ditekuni didukung dengan kemampuan pemanfaatan teknologi.

Namun sayangnya, data-data mengenai implementasi Pendidikan Teknohumanistik ini sendiri masih sangat kurang adanya. Hanya beberapa peneliti yang tertarik untuk meneliti mengenai model pembelajaran ini. Selain itu, penelitian tersebut hanya berfokus pada pembentukan karakter bangsa yang notabene telah diimplementasikan di dalam pendidikan di Indonesia. Utamanya diimplementasikan di dalam penggunaan kurikulum KTSP. Lebih jauh, penelitian akan pemanfaatan ICT seperti SNS di dalam pendidikan masih sangat sedikit adanya. Padahal pemanfaatan ICT merupakan salah satu ciri di dalam Pendidikan teknohumanistik itu sendiri. Sehingga ini menjadi sebuah hal yang patut untuk dikritisi di mana model pembelajaran ini haruslah berfokus tidak hanya di dalam implementasi pembangunan karakter yang baik saja. tetapi juga mengindahkan perubahan-perubahan yang terjadi di lingkungan sekitar seperti pemanfaatan ICT.

\section{SIMPULAN DAN SARAN}

Melalui pemaparan di atas, maka dapat disimpulkan bahwa jumlah dosen pengajar yang mengimplementasikan SNS masih sedikit adanya. Selain itu, pemanfaatan SNS di dalam pembelajaran untuk mendukung implementasi Pendidikan Teknohumanistik masih sangat kurang di mana hanya beberapa SNS yang digunakan untuk beberapa tujuan pembelajaran saja. Hal ini bisa jadi dikarenakan kesadaran dosen Jurusan Pendidikan Bahasa inggris untuk melaksanakan perkuliahan terhadap calon-calon guru bahasa Inggris masih sangat rendah ataupun kemampuan menggunakan SNS ini yang masih sangat rendah. Namun, mahasiswa yang merupakan Digital Natives mengetahui dengan benar manfaat pemanfaatan SNS untuk menopang perkuliahan mereka. Sehingga, mereka menggunakan SNS tidak hanya karena tuntutan perkuliahan, tetapi juga untuk membantu mereka meningkatkan kualitas pembelajaran mereka. Oleh karena itu, melihat fakta ini, dosen pengajar haruslah memanfaatkan situasi ini dan menyadari akan pentingnya mengimplementasikan SNS di dalam perkuliahan. Tidak hanya untuk membantu meningkatkan kualitas pembelajaran, tetapi juga untuk membekali calon guru dengan pengalaman pemanfaatan teknologi yang diharapkan dapat mereka terapkan pula ketika mereka menjadi pengajar bahasa Inggris setalh tamat nantinya.

\section{DAFTAR PUSTAKA}

Abao, E. de L., Boholano, H. B. \& Dayagbil, F.T. (2015). Engagement to Social networking: Chalengges and Opportunities to Educators. European Scientific Journal 11 (16). Hal. 173-191

Bicen, Huseyin \& Uzunboylu, Huseyin. (2013). The Use of Social Networking Sites in Education; A Case Study of Facebook. Journal of Universal Komputer Science, 19 (5). Hal. 658671.

Brady, K. P., Holcomb, L. B., \& Smith, B. V. (2010). The Use of Alternative Social Networking Sites in Higher Educational Settings: A Case Study of the ELearning Benefits of Ning in Education. Journal of Interactive Online Learning, 9 (2). Hal. 151-170.

Dantes, Nyoman. (2014). Landasan Pendidikan: Tinjauan dari Dimensi Makropedagogis. Yogyakarta: Graha IImu.

Doghmi, A.A., Shalabi, H.A., Odeh, J.M., Andraws, S., Awajan, A., \& Alrabea, A.I. (2013). The Academic Use of Social networks among University Students in Jordan. International Journal of Komputer Science Issues. 10(5). Hal. 134-142.

Fori, Emmanuel. (2016). The Effects of Social Networking Sites on the 
Academic Performance of the Engineering Students in the University of Maiduguri State, Nigeria. IJCSI International Journal of Computer Science Issues. 13(1). Hal. 76-85.

Khedo, K.K., Ally, S.M.R., Suntoo, R. \& Mocktoolah, A. (2012). Case Studies on the Use of Online Social Networking in Formal Education. International Journal of Komputer Application. 45(8). Hal. 21-26.

Labus, A., Simic, K., Barac, D. Zrakic, M. D. \& Radenkovic, M. (2012). Integration of Social network Services in EEducation Process. Metalurgia International 17(7). Hal. 161-169.

Lasmawan, Wayan. (2015). Pengembangan Perangkat Pembelajaran E-learning Mata Kuliah Wawasan Pendidikan Dasar, Telaah Kurikulum Pendidikan Dasar, pendidikan IPS Sekolah Dasar, Perspektif Global dan Problematika Pendidikan Dasar. Jurnal Pendidikan Indonesia 4(1). Hal. 556-570

Natajaya, I Nyoman \& Dantes, Nyoman. (2015). Rancangan Model Transpormasi Pendidikan Teknohumanistik yang Terintegrasi dengan Pembelajaran Tematik di Sekolah Dasar. Jurnal Pendidikan Indonesia 4(1). Hal 599-611.

Menteri Pendidikan dan kebudayaan republic Indonesia. (2013). Salinan Lampiran Peraturan Menteri Pendidikan dan Kebudayaan Republik Indonesia Nomor 65 tahun 2013: Standar proses Pendidikan dasar dan
Menengah. Menteri Hukum dan Ham Republik Indonesia. Hal 1-13

Mundiri, Akmal. (2012). Pendidikan Teknohumanistik berbasis Core Ethical Value. Jurnal At-Tajdid 1(1). Hal. 37-47

Nawawi, Ridwan. 2008. Analisis Dan Perancangan Aplikasi Jejaring Sosial Penjualan Berbasis Web.

Prensky, Marc. (2001). Digital Natives, Digital Immigrants. On the Horizon 9 (5). Hal 1-6.

Santyasa, I W., Warphala, I W. S., \& Tegeh I M. (2015). Validasi dan Implementasi Model-model Student Centered Learning untuk Meningkatkan penalaran dan Karakter Siswa Sekolah Menengah Atas. Jurnal Pendidikan Indonesia 4(1). Hal 512-527.

Srivastava, Preeti. (2012). Social Networking \& Its Impact on EducationSystem in Contemporary Era. International Journal of Information Technology Infrastructure, 1(2). Hal.11-18.

Stanciu, A., Mihai F., \& Aleca O. (2012). Social Networking as an Alternative Environment for Education. Accounting and Management Information Systems, 11 (1). p. 56-75.

Tariq, W., Mehboob, M., Khan, M.A., Ullah, F. (2012). The Impact of Social media and Social Networks on Education and Students of Pakistan. IJCSI International Journal of Computer Science Issues. 9(3). Hal. 407-411 